\title{
THE KILLERS
}

$\infty$ 
This page intentionally left blank 


\section{THE RLLES}

A NARRATIVE

OF

REAL LIFE IN PHILADELPHIA

GEORGE LIPPARD

E D I T E D B Y

MATT GOHEN AND EDLIE L. WONG

\section{$\overline{\text { PENN }}$}

UNIVERSITY OF PENNSYLVANIA PRESS

P H I L A D E L P H I A 
Copyright $@ 2014$ University of Pennsylvania Press

All rights reserved.

Published by

University of Pennsylvania Press

Philadelphia, Pennsylvania 19104-4112

www.upenn.edu/pennpress

Printed in the United States of America on acid-free paper

$\begin{array}{llllllllll}1 & 3 & 5 & 7 & 9 & 10 & 8 & 6 & 4 & 2\end{array}$

Library of Congress Cataloging-in-Publication Data

Lippard, George, 1822-1854.

The killers : a narrative of real life in Philadelphia / George Lippard; edited by Matt Cohen and Edlie L. Wong. - 1st ed.

p. cm.

Appendix 1: "Life and Adventures of Charles Anderson Chester."

Includes bibliographical references and index.

ISBN 978-0-8122-4624-7 (hardcover : alk. paper)

1. Riots-Pennsylvania-Philadelphia-Fiction. 2. Philadelphia(Pa.)-

History-19th century-Fiction. I. Cohen, Matt, 1970- II. Wong, Edlie L.

III. Life and adventures of Charles Anderson Chester. IV. Title.

PS2246.L8K55 2014

$813 ' .3-\mathrm{dc} 23$

2013047982 